\title{
Paweł Łapiński: Deklinowanie wiosny albo zgrywa z Schulza
}

„The Grid. A digital frontier. I tried to picture clusters of information as they moved through the computer. What did they look like? Ships? Motorcycles? Were the circuits like freeways? I kept dreaming of a world I thought I'd never see. And then one day... I got in".

Tron: Legacy, reż. Joseph Kosinski

Gra fabularna. Gra tekstowa, paragrafowa. Gamebook. Już same nazwy tych gatunków sugerują ich literacką proweniencję. Nic dziwnego - w końcu wiele z nich, szczególnie w przypadku gier fabularnych (RPG), bazuje czy to na klasyce literatury fantasy (Śródziemie na podstawie Tolkiena), czy s-f (Cyberpunk 2020, czerpiący garściami z powieści Williama Gibsona i Philipa K. Dicka), a nawet z klasyki horroru gotyckiego (Zew Cthulu na bazie H. P. Lovecrafta). Do tego zaszczytnego grona dołączył niedawno Bałwochwał, nasycony treścią oraz duchem twórczości Brunona Schulza. Dzieło Mariusza Pisarskiego i Marcina Bylaka, zasadniczo niszowe, w innych okolicznościach być może funkcjonowałoby jedynie w wąskim kręgu schulzologów czy schulzofilów. Kiedy jednak inicjatywa tego typu uzyskuje dotację Ministra Kultury i Dziedzictwa Narodowego, nie sposób już przejść obok niej obojętnie. Zmysł krytyczny nęci tu szczególnie drugi człon nazwy tej szacownej instytucji. Usankcjonowanie Bałwochwała pieczęcią państwowego hegemona niemalże $\mathrm{z}$ automatu przenosi go na inny level i wpisuje w oficjalną narrację badań nad polskim dziedzictwem literackim. Gra paragrafowa Pisarskiego i Bylaka sytuuje się co prawda na rubieżach tego nurtu, jest to jednak miejsce, z którego często widać dużo więcej niż z mainstreamowych rejonów opromienionych blaskiem centrum ${ }^{\mathbf{1}}$.

\section{Subiekci i kataryniarze}

Nadmieńmy od razu, że premierze gry towarzyszył artykuł autorstwa Pisarskiego ${ }^{2}$, opisujący szczegółowo motywacje jej twórców, przedstawiający ich założenia

1 Por. J. Majmurek, Pokochać ulicę Krokodyli, w: Schulz. Przewodnik Krytyki Politycznej, Warszawa 2012, s. 8-11.

2 M. Pisarski, Schulz na cyfrowo. Gra paragrafowa „Bałwochwal”, „Czas Kultury” 2014, nr 1, s. 70-75. 
wyjściowe, a czasem nawet posuwający się do oceny jakościowej ostatecznego efektu prac. Nieskromność autora łatwo można w tej sytuacji wybaczyć, artykuł jest bowiem zwyczajnie ciekawy i inspirujący, dostarcza wartościowych informacji nie tylko o samej grze, ale także o innych multimedialnych odsłonach twórczości Schulza.

W każdym innym kontekście taka publikacja trąciłaby kryptoreklamą, ponieważ autor tylko mimochodem wspomina, że pisze o własnym dziele. A jednak z uwagi na całkowicie niekomercyjny charakter tego przedsięwzięcia trudno oskarżyć Pisarskiego o nieuczciwe zabiegi marketingowe. Jego artykuł wydaje się raczej motywowany czysto fanowskim zapałem, wymagającym od każdego schulzofila drobiazgowego omawiania działań poświęconych obiektowi kultu.

\section{Witaj, Śmiałku!}

Czym zatem jest Bałwochwał według deklaracji samego współtwórcy? „Batwochwat to wnuk dwóch paraliterackich gatunków z lat 70. i 80. ubiegłego wieku" - wyjaśnia Pisarski, dodając, że chodzi mu o połączenie analogowej gry paragrafowej oraz komputerowej, tekstowej gry przygodowej ${ }^{3}$. Aspekty techniczne wymagały przetransponowania Schulzowskiej narracji z pierwszej osoby na drugą, ale poza tym jednym zabiegiem treść oryginalnych tekstów pozostała zasadniczo nietknięta. Autorzy nie podszywają się pod Schulza, ograniczając się do bezpiecznego korzystania z gotowych leksji, które komponują w intrygujący kolaż. Powstaje w ten sposób nie tyle pozszywany sztucznie patchwork o widocznych liniach cięcia i szycia, ile spójne naddzieło, skrzące się skondensowaną Schulzowską frazą, nagromadzeniem typowych dla autora motywów, postaci, zwrotów - coś na kształt Schulza w pigułce.

Grając w Bałwochwała, zgodnie z regułami gatunku zagłębiamy się w Schulzowskie uniwersum, poruszając od paragrafu do paragrafu i kierując zachowaniem postaci według linków podsuwanych pod każdym kolejnym paragrafem. Podobnie jak w papierowych grach, również tutaj niektórym leksjom towarzyszy losowe generowanie zdarzeń poprzez rzut (cyfrową) kostką. To wszystko elementy znane doskonale $\mathrm{z}$ tradycyjnych, analogowych gier paragrafowych.

Prawdziwie nową jakością jest muzyka Artura Klimaszewskiego, stanowiąca jednocześnie element diegetyczny i metatekstowy. Z jednej strony nie można odmówić jej wartości ilustracyjnej, gdyż nastrojem doskonale wpisuje się w treść kolejnych paragrafów i zawarte w nich niepokojące, oniryczne sceny. Z drugiej strony jednak jest to korespondencja tylko na poziomie afektywnym, zmysłowym. Jeśli bowiem wsłuchamy się w tło muzyczne uważniej, okaże się, że ma ono często działanie przeciwne do ilustracyjnego. Słuchana uważnie muzyka wytrąca 
czytelnika z wsiąkania w Schulzowski świat, pobrzmiewa w niej bowiem sporo elektroniki, gitary elektrycznej czy wokaliz, nieprzystających do przesyconego międzywojennym imaginarium Drohobycza Sklepów cynamonowych.

Nie bez znaczenia jest też długość kolejnych utworów - motyw muzyczny towarzyszący danemu paragrafowi nie jest zapętlony, jak to często bywa w grach komputerowych, tylko cichnie po czasie potrzebnym na przeczytanie danej sceny oraz zapoznanie się z towarzyszącymi jej opcjami fabularnymi. Nastająca bezlitośnie cisza coraz bardziej natrętnie sugeruje, żeby dokonać wyboru bez dłuższego namysłu i przejść dalej - jeżeli chce się pozostać w świecie gry, należy odrzucić typowe dla tego typu rozrywek budowanie strategii i kalkulacje uwzględniające potencjalne zyski i straty związane z konkretnymi postawami. W tradycyjnych (komputerowych) grach przygodowych czy RPG autorzy często premiowali u graczy konkretne postawy (również moralne) czy strategie, a sukces w grze zależał w dużej mierze od wydedukowania, czego oczekuje się od bohatera. W Batwochwale natomiast cichnąca muzyka zniechęca do takiej hermeneutycznej postawy i motywuje gracza do podejmowania decyzji intuicyjnie, bez próby rozszyfrowania zasad gry, zmusza do rzucenia się bezwiednie w porywający nurt Schulzowskiej narracji.

Omówione elementy konstrukcyjne Bałwochwała to jednak tylko warstwa wierzchnia, charakterystyczne elementy gatunkowe, dzięki którym można było w odpowiednim momencie ułożyć grę w odpowiedniej przegródce, co na pewno miało znaczenie podczas ubiegania się o środki MKDiN. Nie dajmy się jednak zwieść pozorom. $\mathrm{W}$ istocie najważniejsze w Bałwochwale jest nie to, czym jest formalnie, ale to, czego jest emanacją, a przede wszystkim - co zwiastuje.

\section{Deklinowanie wiosny}

Najpierw jednak zboczymy trochę z ścieżki oficjalnej narracji, narzuconej ministerialnym usankcjonowaniem i odautorskim komentarzem Pisarskiego, i wyjaśnimy sobie, czym Bałwochwal nie jest, choć pozornie wydaje się być.

Na pewno nie spełnia on wszystkich wymagań, jakie stawiali grze chociażby Johan Huizinga czy Roger Caillois, na przykład dlatego, że podczepiając się pod konkretny gatunek, nie przestrzega reguł, które zwyczajowo w nim obowiązują. W klasycznej grze paragrafowej każda $\mathrm{z}$ oferowanych do wyboru opcji ma popychać akcję do przodu, daje graczowi realną szansę na zbliżenie się do określonego celu, szansę na nagrodę, zwycięstwo, wynik punktowy. Tymczasem Bałwochwat tak naprawdę nie oferuje żadnego konkretnego celu, do którego mógłby dążyć gracz od samego początku gry.

„Typowy dla prostych gier paragrafowych happy end byłby tworem sztucznym" - przyznaje sam Pisarski, dodając, że nie każdy czytelnik dociera do 
końca 4 . Twórcy z rozmysłem co rusz wysyłają graczy w „odnogi czasu”, z których można się wydostać, zaczynając rozgrywkę od nowa. Oficjalnie jest to oczywiście motywowane nawiązaniem do stylistyki Schulza, jego koncepcji przestrzeni i czasu. Gdyby jednak oceniać Bałwochwała wyłącznie pod kątem grywalności, ukaże nam się on jako zlepek literackich wątków i przestrzeni, które udało się złączyć w koherentną diegezę, ale już nie ułożyć w zajmującą historię, która mogłaby wciągnąć gracza samą tylko intrygą.

W dodatku o ile w klasycznej grze każda z towarzyszących danej leksji opcji postępowania rzeczywiście prowadzi do dalszego rozwoju akcji, o tyle w Batwochwale często trafiają się paragrafy, w których podane do wyboru linki podsuwają nie konkretną akcję, lecz na przykład zmianę stanu wewnętrznego bohatera bądź aktywność raczej umysłową niż fizyczną (w stylu „Deklinujesz dalej tę wiosnę").

W dodatku czasami, zamiast dokonywać wyboru wśród różnych opcji postępowania, bohater może wybierać spośród typów zachowań innych postaci czy też zmian otoczenia. Tutaj już Bałwochwał wydaje się definitywne zrywać z konwencją gry, w której od podsuwanych do wyboru opcji oczekiwalibyśmy posuwania akcji do przodu. Czyżby więc Bałwochwał należał do grona dzieł spod znaku hipertekstu, których podstawową zaletą dla czytelnika jest swobodne poruszanie się po literackim uniwersum ${ }^{\mathbf{5}}$ Taka interpretacja również zdaje się na pewnym etapie utykać w „pętli czasu”, albowiem od hipertekstu oczekiwalibyśmy jednak konkretnej fabuły, choćby i skrajnie wielowątkowej i rozbitej na wiele alternatywnych tropów, to jednak w ten czy inny sposób prowadzącej czytelnika przez świat przedstawiony. Tymczasem Bałwochwał to raczej niesiony onirycznymi inspiracjami zlepek scen, wizji, literacki próbnik stylu, markownik pełen synestezyjnych doznań.

Znaki zapytania, które pojawiają się podczas analizy Bałwochwała, jego nieuchwytność, lawirowanie między rejestrami sugerują zgoła inne wpływy gatunkowe - Bałwochwat to pierwszorzędna zgrywa.

\section{Ariergarda kultury narodowej}

Próżno szukać definicji zgrywy u Huizingi czy Caillois, na początku zadowolimy się więc słownikiem Doroszewskiego, który sytuuje ją gdzieś między kpiną, nabijaniem się, zakłamaniem i pozerstwem. Trzeba tu od razu zaznaczyć, że kpina Bałwochwała to nie szlachetne pokłosie figli średniowiecznych sowizdrzałów czy błaznowania przenikliwych Stańczyków. To raczej echo dużo bliższej na planie czasowym tradycji punkowych fanzinów, kultury alternatywnej lat osiem-

4 Ibidem, s. 71.

5 Por. http://www.ha.art.pl/rekopis/instrukcja.html (dostęp: 3.07.2017). 
dziesiątych, która część swojej anarchizującej wywrotowości przeniosła w latach dziewięćdziesiątych i na początku XXI wieku na internetowe fora i listy dyskusyjne. Zgrywa tego rodzaju to po prostu trashowa zabawa nieuznająca żadnych świętości, traktująca w niespecjalnie wysmakowany sposób wszelkie autorytety. Nieznająca ograniczeń zabawa z materią kultury, czerpiąca garściami z kiczu i wytworów masowej wyobraźni.

W pewnym sensie zgrywą było już sięgnięcie przez autorów do tak archaicznego gatunku jak gra paragrafowa sprzedawana onegdaj w kioskach Ruchu pod postacią krzywo sklejonych zeszytów z makulaturowego papieru. Bezpośrednim nawiązaniem do tej stylistyki jest chociażby rozmyślne zastosowanie w Bałwochwale ubogiej, maszynowej czcionki (Arial? Courier?). Ten ewidentnie kampowy sentyment do zapomnianego gatunku przypomina nieco cykliczność nawracających modowych trendów, która dzisiejszym czterdziestolatkom każe znów ubierać się $\mathrm{w}$ kreszowe dresy i marmurkowy dżins. To puszczenie oka do potencjalnych odbiorców i zawarcie z nimi przymierza krwi - zgrywa opiera się bowiem na plemiennym współporozumieniu. Na takich rozrywkach się wychowaliśmy - zdają się mówić autorzy - więc teraz, kiedy dorośliśmy, zabierzemy się do zabawy z kulturowym dziedzictwem po swojemu.

Najważniejszym elementem zgrywy jest jej całkowita autonomia i immunitet na wartościowanie. Zgrywy nie da się ocenić ani zinterpretować, a kiedy ją przycisnąć na ten czy inny temat, zaczyna bezczelnie rechotać albo robi głupią minę. Jednocześnie, przez ożywczą bezinteresowność zgrywy i jej nieskażenie konwencjami, pozycja zgrywusa bywa czasem doskonałym punktem obserwacji rzeczywistości. Zgrywa wymyka się wszelkim kategoryzacjom i szufladkom, a jednocześnie zachowuje pewne szanse na całkiem poważną komunikację z odbiorcą.

Zgrywa kreatywna i pomysłowa jest być może największym wyróżnieniem, jakie może spotkać pisarza - świadczy o ogromnym potencjale jego dzieła i o jego oryginalności. Do prawdziwej zgrywy nadają się bowiem tylko najlepsze jakościowo produkty, jest ona też najczęściej dziełem wiernych czytelników, fanów, zaangażowanych znawców i miłośników danej twórczości. Zgrywa to jeden z objawów bezgranicznej miłości, a każdy poważny zgrywus wie, że jego idolowi nie zaszkodzi nawet najokrutniejsze szyderstwo czy ironia. W pewnym sensie jest to więc kolejny sposób na głoszenie wielkości danego twórcy, a jednocześnie objaw skrajnie autoironicznego podejścia do własnej nim fascynacji. Pod tym względem zgrywa ma pewnie wiele wspólnego z pastiszem, choć jednocześnie absolutnie odrzuca wszelkie ambicje literackie czy intertekstowe, przypisywane często temu gatunkowi ${ }^{6}$, i skupia moc twórczą na inteligentnej zabawie. Nie trzeba tu chyba dodawać, że skrajnie neurotyczny i manieryczny Schulz nadaje się na obiekt zgrywy doskonale, a przesycenie jego frazą nie tylko treści samych paragrafów 
(co naturalne), ale również metatekstu (linki z opcjami działania, didaskalia gry) stanowi właśnie klasyczny element zgrywy.

Pisząc o peryferyjnej pozycji, na jakiej sytuował się Schulz w konstelacji polskiej kultury, Jakub Majmurek wspomina, że peryferia nie muszą być miejscem zapóźnienia wobec centrum czy separacji od niego - wręcz przeciwnie, czasami pozwalają widzieć lepiej, będąc miejscem, gdzie „na wierzch wychodzi to, co centrum pracowicie ukrywa"7. Pozycja ta wydaje się zaskakująco zbieżna z tą deklarowaną przez jeden z klasycznych ruchów zgrywy, czyli środowisko „Brulionu” i Totartu. Totartowcy, jak to ujął ich naczelny zgrywus, Zbigniew Sajnóg, jako ariergarda narodowej kultury pilnowali, „by nikt nie wyrżnął jej w dupę”.

\section{Bazakbal vs Gonzalo III: Ostatnie starcie}

Na tym etapie w zasadzie można by zakończyć peany nad dziełem Pisarskiego i Bylaka, a samemu Schulzowi pogratulować, że wciąż potrafi wzbudzać w swoich wielbicielach takie emocje i inspirować równie pomysłowe inicjatywy. Trzeba bowiem uczciwie stwierdzić, że autorzy gry wywiązali się po dwakroć ze swojego fanowskiego obowiązku, czyli ewangelicznego szerzenia dobrej nowiny i popularyzowania twórczości autora.

A jednak najważniejsze zjawisko zdaje się tu kryć między wierszami Batwochwat to bowiem nie tylko pojedyncza schulzofilska zabawka, zachęcająca laików do ruszenia głębiej w twórczość autora, a znawcom oferująca, zapewne, kilka chwil rozrywki, wzbudzająca uśmiech podziwu bądź grymas zazdrości. To nade wszystko jutrzenka całkiem nowego, bezlitośnie kreatywnego podejścia do literackiego dziedzictwa.

Sam Pisarski wspomina o tym dość nieśmiało i ogólnikowo jako o „badaniu narracyjnego potencjału tekstowych form cyfrowych"8. Kiedy jednak zamienimy przyciężkie słowo „badanie” na bardziej frywolną „zabawę”, na horyzoncie zaczyna się rysować kształt wyczekiwanej od dawna szansy na popkulturyzację polskiego dziedzictwa literackiego.

Pierwszy klucz podsuwa już informacja zawarta na stronie wydawcy Batwochwała, krakowskiego „Ha!artu”, informująca, że gra powstała „jako celebracja pierwszego roku obecności autora Sklepów cynamonowych w Domenie Publicznej oraz jako zachęta do podobnych inicjatyw, które odchodziłyby od czystej digitalizacji w stronę twórczego wykorzystania dziedzictwa literatury polskiej"9. Brzmi zachęcająco, prawda? Po kolejne literackie światy nie trzeba się-

7 J. Majmurek, op. cit., s. 9.

8 M. Pisarski, op. cit., s. 74.

9 Zob.http://ha.art.pl/prezentacje/29-projekty/2817-mariusz-pisarski-marcin-bylak-balwochwalinteraktywna-fikcja-sieciowa-na-podstawie-opowiadan-brunona-schulza.html (dostęp: 3.07.2017). 
gać daleko - czy chociażby Witkacowska menażeria międzywojennych freaków oraz język autora - niemalże równie manieryczny i kreatywny, co u Schulza - nie nadaje się doskonale na świat kolejnej gry?

Zresztą związana z domeną publiczną kwestia praw autorskich ogranicza przede wszystkim wydawców oficjalnych, tymczasem produkcje półoficjalne, czy całkiem amatorskie, fanowskie, nie muszą się przejmować żadnymi ograniczeniami. Popuszczając wodze fantazji, można tu sobie wyobrazić epickie narracje rodem z komiksowych crossoverów, czyli albumów, w których bohaterowie różnych serii spotykają się we wspólnych fabułach. Na przykład grę psychologiczno-alkoholową, w której podstarzały Rysiek Lewandowski próbuje w warszawskiej knajpie odwieść pewnego znanego pisarza od samospalenia się pod Pałacem Kultury. Albo coś dla wielbicieli kryminalnych łamigłówek: wirtualne zaproszenie do innego lokalu w stolicy, w którym profesor Tutka wraz z redaktorem Kolanko, niczym Holmes i Watson, planowaliby schwytanie arcyłotra Filipa Merynosa.

Zresztą, dlaczego ograniczać się do mashupowania literackich fabuł tylko i wyłącznie z narzuconej przez autora perspektywy? W końcu prędzej czy później można się również spodziewać udostępnienia $\mathrm{w}$ sieci odpowiednich programów i aplikacji do samodzielnego tworzenia gier paragrafowych czy komponowania hipertekstów. Po wybraniu elektronicznej wersji ulubionej lektury użytkownik będzie prowadzony przez cyfrowego asystenta krok po kroku przez cały proces kreacji: program sam zmieni osoby narracji, podzieli tekst na sekcje, wątki, tropy, pomoże ustalić szczegóły rozgrywki i zbudować fabularną drabinkę przyczynowo-skutkową, a na koniec ułożyć ścieżkę dźwiękową z dostępnych legalnie utworów. Wówczas wkroczymy w erę Ogniem i mieczem opowiadanego z perspektywy Bohuna oraz Lalki, w której głównym celem gracza będzie pomoc Izabeli w unikaniu Wokulskiego. Marek Arens wreszcie zrezygnuje z pogoni za Jowitą i skupi się na karierze sportowej, a Zabawa, Warszawiak i Orsaczek doczekają się nowych ciężarówek. Brzmi zachęcająco? Do dzieła więc, zgrywusy. Aim, fire, reload, repeat! 